ARTÍCULOS

\title{
Wood anatomy of five species from Mozambique and its potential application
}

\author{
Anatomía de la madera de cinco especies de Mozambique y su aplicación potencial
}

\author{
Narciso Fernando Bila a , Reinaldo Luis a, Thaís Alves Pereira Gonçalves ${ }^{\text {b }}$, \\ Graciela Inés Bolzon de Muñiz ${ }^{c}$, Silvana Nisgoski ${ }^{\text {c* }}$ \\ ${ }^{a}$ Universidade Eduardo Mondlane, Faculdade de Agronomia e Engenharia Florestal, \\ Departamento de Engenharia Florestal, Secção Tecnologia da Madeira, Mozambique, Africa. \\ ${ }^{\mathrm{b}}$ Museu Paraense Emílio Goeldi, Belém, PA, Brasil. \\ *Corresponding author: ${ }^{\mathrm{c}}$ Federal University of Parana, Department of Forest Engineering and Technology, \\ Av. Pref. Lothário Meissner, 632, Jardim Botânico, 80.210-170, Curitiba, PR, Brazil, \\ phone (55) 41 -3360-4275, silvana.ufpr@gmail.com
}

\begin{abstract}
SUMMARY
Wood trade is strongly dependent on global economic conditions. In Africa, the market for tropical wood also has dynamic changes. In Mozambique, the international demand for wood comes mainly from emerging economies such as China and India. Almost $70 \%$ of the country is still covered by forests and other woody vegetation. There are many species with favorable properties for wood commerce, although, at present, this is restricted to a few species. We analyzed the wood anatomy of Acacia nigrescens, Combretum imberbe, Icuria dunensis, Pericopsis angolensis and Sterculia appendiculata and comment about properties and potential use based on their anatomical composition. In general, the species presented wood diffuse pores, simple perforation plates, alternate intervessel pits, deposits in vessels; abundant axial parenchyma; multiseriate rays, very thick-walled fibers and mineral inclusions. Based on anatomical characteristics, the studied species have great potential for use in panels industry, furniture, floor, structures and craftwork.
\end{abstract}

Key words: Africa, native species, wood structure, wood use.

\section{RESUMEN}

El comercio de madera depende en gran medida de las condiciones económicas globales. En África, el mercado de las maderas tropicales también tiene cambios dinámicos. En Mozambique, la demanda internacional de madera proviene principalmente de las economías emergentes como China e India. Casi el 70 \% del país está todavía cubierta por bosques y otra vegetación leñosa. Hay muchas especies con propiedades favorables para el comercio de madera, pero en la actualidad esto está restringido a unas pocas especies. Se analizó la anatomía de la madera de Acacia nigrescens, Combretum imberbe, Icuria dunensis, Pericopsis angolensis y Sterculia appendiculata y se comenta las propiedades y el uso potencial en función de su composición anatómica. En general, las especies tienen porosidad difusa, placas de perforación simple, punteaduras intervasculares alternas, depósitos en los vasos; parénquima axial abundante; rayos multiseriados, fibras de paredes muy gruesas e inclusiones minerales. Según las características anatómicas, las especies estudiadas tienen un gran potencial para uso en la industria de paneles, muebles, pisos, estructuras y artesanía.

Palabras clave: África, especies nativas, estructura de la madera, uso de la madera.

\section{INTRODUCTION}

The market for tropical wood in Africa is dynamic. Domestic conversion of logs expanded between 2009 and 2011, while export decreased due to restrictions imposed by many countries. Sawn wood production increased modestly and in 2011 it was $13 \%$ of tropical wood production. Although there is an external market for African tropical timber, trade mainly depends on developing countries and is affected by global economic conditions (ITTO 2012).
In 2014 , the value of wood exports was US\$ 123 million (2.6\% of total the country total exports) (MRE 2015).

Mozambique is in Southeast Africa and covers a surface area of $799,380 \mathrm{~km}^{2}$, of which 54.8 million hectares (about $70 \%$ of national territory) is covered by forests and woody vegetation. Of this area, 26.9 million hectares is productive forest, 13.2 million is forests in reserves and the remaining 14.7 million is covered by multiple-use forests. However, even considering favorable aspects, such as availability of many easily-workable species of wood, 
with a suitable relationship between density and mechanical resistance, wood market and uses are currently restricted to a few species, such as Afzelia quanzensis Welw. (Chanfuta), Pterocarpus angolensis DC. (Umbila), Millettia stuhlmannii Taub. (Panga-panga) e Androstachys johnsonii Prain. (Mecrusse). This situation has caused pressure on extraction of these species, resulting in threats to the environment with possible extinction of some species (DNTF 2009).

Knowledge of anatomical characteristics combined with technological properties of wood allows appropriate use. Studies of native species are important to reduce the impact on traditionally used ones (Ali et al. 2008) and also to improve the efficiency of forest exploitation (Uetimane et al. 2009). Such research also contributes to better processing methods, resulting in improved quality of final products (Ogle and Nhantumbo 2006).

The present work analyzes the wood anatomy of five lesser known species in Mozambique. We comment about properties and potential use based on their anatomical composition. Our main objective is to contribute with information to the use of alternative species, to add more economic value to wood trade and reduce the impact on traditionally used species.

\section{METHODS}

Species (table 1) were collected randomly in sawmills of Nampula Province $\left(15^{\circ} 07^{\prime} \mathrm{S} 39^{\circ} 15^{\prime} \mathrm{E}\right)$ in northern Mozambique. Disks with $4 \mathrm{~cm}$ were taken at the base of two logs per species. From these disks, samples oriented in transversal, longitudinal radial and longitudinal tangential sections were obtained for histological analyses. The wood was collected based on popular name in sawmills, after anatomical structure was verified and identification was confirmed.

General characteristics were described based on Coradin and Muñiz (1992). The microscopic descriptions were based on the recommendations of the International Asso- ciation of Wood Anatomists (IAWA 1989). The measures of cellular elements were taken with an Olympus CX40 microscope, with micrometer scale and digital camera attached. We obtained 25 data for tangential vessel diameter, vessel frequency (vessels $\left.\mathrm{mm}^{-2}\right)$, ray width $(\mu \mathrm{m})$, ray height $(\mu \mathrm{m})$ and ray frequency (rays $\mathrm{mm}^{-1}$ ). Results are presented as means followed by the full range (min-max) and standard deviation (sd).

\section{RESULTS}

General characteristics of wood are: (i) Acacia nigrescens presents dark brown heartwood distinctly demarcated from the narrow, whitish yellow sapwood; irregular grain, moderately coarse texture, imperceptible odor, figure based on light and darker streaks in heartwood; (ii) Combretum imberbe presents dark brown heartwood distinctly demarcated from the thin, yellowbrown sapwood; the grain is straight, fine to medium texture, imperceptible odor; (iii) Icuria dunensis shows reddish heartwood and pale yellow to pale pink sapwood; straight grain, fine to medium texture, imperceptible odor; (iv) Pericopsis angolensis presents dark brown to almost black heartwood distinctly demarcated from the whitish to yellowish grey sapwood; interlocked grain, moderately fine texture, imperceptible odor, the wood is strikingly banded or shows a whorled figure; (v) Sterculia appendiculata presents pale brown heartwood indistinctly demarcated from the sapwood; irregular grain, fine to medium texture, imperceptible odor, figure result of banded parenchyma cells.

The wood microscopic anatomical characteristics are summarized in table 2 and illustrated in figures 1-3. All the species presented: (i) diffuse pores; (ii) simple perforation plates; (iii) alternate intervessel pits, (iv) vessel-ray pitting and vessel-parenchyma pitting similar to intervessel pits; (v) abundant axial parenchyma; (v) multiseriate rays; (vi) non-septate and very thick-walled fibers; and (vii) mineral inclusions.

Table 1. List of species studied.

Lista de las especies estudiadas.

\begin{tabular}{lccc}
\hline \multicolumn{1}{c}{ Scientific name } & Commercial name & Family & Commercial class* \\
\hline Acacia nigrescens Oliv. & Namuno & Fabaceae - Mimosoideae & Third \\
Combretum imberbe Wawra & Mondzo & Combretaceae & First \\
Icuria dunensis Wieringa & Ncurri & Fabaceae - Caesalpinioideae & - \\
Pericopsis angolensis Meeuwen & Muanga & Fabaceae -Faboideae & First \\
Sterculia appendiculata K. Schum & Metil & Malvaceae - Sterculioideae & Second \\
\hline
\end{tabular}

*Commercial class is attributed for wood commerce based on rarity, commercial and scientific value. Source: Ministério da Agricultura (2002, 2007). 


\section{DISCUSSION}

Wood anatomy. The dimensions of Icuria dunensis obtained in this study are different from those observed by Wieringa (1999), vessel and ray frequencies are smaller and tangential diameter of vessel, height and width of rays are larger. The wood of Pericopsis angolensis has tangential vessel diameter and vessel frequency similar to those obtained by Uetimane et al. (2009). Ray frequency and height are smaller than those shown by his results. For Sterculia appendiculata, only ray height is smaller than in the results of Uetimane et al. (2009). Variations in cell dimensions were expected, because of the influence of ecological factors and water supply (Carlquist 2001).

Growth rings formation is related to environmental and climatic conditions, such as precipitation index, and the periodicity in climate will affect its formation in some species, being smaller in dry years and larger in rainy ones (Marcati et al. 2008). They are also correlated with wood density (Bouriaud et al. 2005). In the studied species, the presence of growth rings is not observed only in the wood of Sterculia appendiculata.

In general, the vessels are small to medium; few (Sterculia appendiculata) to frequent (Pericopsis angolensis); with simple perforation plate. The tangential diameter of vessels and frequency are important taxonomic characteristics, nonetheless are also influenced by ecological factors related to water availability. On the other hand, vessels with larger diameter or more frequent vessels are more effective for water transport in plants, but can reduce density and wood resistance (Carlquist 2001).

Crystals in axial parenchyma were observed in Acacia nigrescens (Namuno), Pericopsis angolensis (Muanga) and Sterculia appendiculata (Metil), and in almost all ray cells of Combretum imberbe (Mondzo). The difference in crystal type and frequency is associated with plant response to the environment, being observed in greater quantity in drier environments. According to some studies, the formation of oxalate crystals has functions that protect the plant from environment stress, such as excessive mineral inclusion in the soil and herbivore attack (Nakata 2003).

\section{Properties and potential uses based on wood anatomy.}

(i) Drying - the presence of high percentage of axial and radial parenchyma can result in drying defects, such as cracking and warping (Damayanti y Rulliaty 2010). The species with the least presence of axial parenchyma were

Table 2. Summary of anatomical characteristics of studied species. Mean (minimum-maximum), (standard deviation).

Resumen de las características anatómicas de las especies estudiadas. Media (mínimo-máximo), (error estándar).

\begin{tabular}{|c|c|c|c|c|c|c|c|c|c|c|c|}
\hline \multirow[b]{2}{*}{ Species } & \multirow{2}{*}{ GR } & \multicolumn{3}{|c|}{ Vessels } & \multirow{2}{*}{$\begin{array}{c}\text { Axial parenchyma } \\
\text { Type }\end{array}$} & \multicolumn{5}{|c|}{ Rays } & \multirow{2}{*}{ IM } \\
\hline & & $\varnothing$ & $\begin{array}{l}\text { Freq } \\
\mathrm{mm}^{-2}\end{array}$ & Gums & & Ser & Type & $\mathrm{L}$ & $\mathrm{H}$ & $\begin{array}{l}\text { Freq } \\
\mathrm{mm}^{-1}\end{array}$ & \\
\hline $\begin{array}{l}\text { Acacia } \\
\text { nigrescens } \\
\text { (namuno) }\end{array}$ & $\mathrm{Y}$ & $\begin{array}{c}206 \\
(170-240) \\
(22.7)\end{array}$ & $\begin{array}{c}5 \\
(3-8) \\
(1.2)\end{array}$ & $\mathrm{Y}$ & $\begin{array}{l}\text { Aliform and } \\
\text { confluent, marginal } \\
\text { bands }\end{array}$ & $1-3$ & A & $\begin{array}{c}34 \\
(20-50) \\
(6.5)\end{array}$ & $\begin{array}{c}331 \\
(230-590) \\
(86.3)\end{array}$ & $\begin{array}{c}5 \\
(3-7) \\
(1.2)\end{array}$ & $\mathrm{Y}$ \\
\hline $\begin{array}{l}\text { Combretum } \\
\text { imberbe } \\
\text { (mondzo) }\end{array}$ & $\mathrm{Y}$ & $\begin{array}{c}193 \\
(120-270) \\
(37.5)\end{array}$ & $\begin{array}{c}5 \\
(3-8) \\
(1.2)\end{array}$ & $\mathrm{N}$ & $\begin{array}{l}\text { Vasicentric and } \\
\text { confluent, marginal } \\
\text { bands }\end{array}$ & $1-2(3)$ & $\mathrm{D}$ & $\begin{array}{c}37 \\
(30-50) \\
(6.8)\end{array}$ & $\begin{array}{c}416 \\
(220-800) \\
(142.8)\end{array}$ & $\begin{array}{c}9 \\
(6-13) \\
(1.6)\end{array}$ & $\mathrm{Y}$ \\
\hline $\begin{array}{l}\text { Icuria dunensis } \\
\text { (ncurri) }\end{array}$ & $\mathrm{Y}$ & $\begin{array}{c}173 \\
(130-210) \\
(21.1)\end{array}$ & $\begin{array}{c}5 \\
(3-7) \\
(0.9)\end{array}$ & $\mathrm{Y}$ & $\begin{array}{l}\text { Aliform confluent, } \\
\text { in marginal bands }\end{array}$ & $2-3$ & B & $\begin{array}{c}32 \\
(20-40) \\
(6.5)\end{array}$ & $\begin{array}{c}250 \\
(418-650) \\
(113.3)\end{array}$ & $\begin{array}{c}6 \\
(4-7) \\
(0.9)\end{array}$ & $\mathrm{N}$ \\
\hline $\begin{array}{l}\text { Pericopsis } \\
\text { angolensis } \\
\text { (muanga) }\end{array}$ & $\mathrm{Y}$ & $\begin{array}{c}91 \\
(70-120) \\
(12.6)\end{array}$ & $\begin{array}{c}27 \\
(17-39) \\
(5.6)\end{array}$ & $\mathrm{Y}$ & $\begin{array}{l}\text { Vasicentric, } \\
\text { aliform, confluent, } \\
\text { marginal bands }\end{array}$ & $3-5$ & A & $\begin{array}{c}53 \\
(30-70) \\
(11.0)\end{array}$ & $\begin{array}{c}225 \\
(170-400) \\
(54.1)\end{array}$ & $\begin{array}{c}3 \\
(1-5) \\
(1.3)\end{array}$ & $\mathrm{Y}$ \\
\hline $\begin{array}{l}\text { Sterculia } \\
\text { appendiculata } \\
\text { (metil) }\end{array}$ & $\mathrm{N}$ & $\begin{array}{c}226 \\
(150-330) \\
(40.7)\end{array}$ & $\begin{array}{c}2 \\
(1-3) \\
(0.7)\end{array}$ & $\mathrm{N}$ & Bands & $\begin{array}{l}1 \text { and } \\
4-10\end{array}$ & $\mathrm{C}$ & $\begin{array}{c}107 \\
(40-200) \\
(40.5)\end{array}$ & $\begin{array}{c}855 \\
(300-1250) \\
(242.2)\end{array}$ & $\begin{array}{c}2 \\
(1-4) \\
(0.6)\end{array}$ & $\mathrm{Y}$ \\
\hline
\end{tabular}

*Legend: Y - presence; $\mathrm{N}$ - absence; GR - Growth rings; Vessels - $\varnothing$ - tangential diameter, Freq $\mathrm{mm}^{-2}$ - vessels per mm²; Rays - Ser - width (number of cells), Type - A (all cells procumbent), B (body cells procumbent with 1 to 2 rows of upright and square marginal cells), C (body cells procumbent with mostly 2-4 rows of upright and/or square marginal cells), D (procumbent, square and upright cells mixed throughout the ray), $\mathrm{L}-$ width ( $\mu \mathrm{m})$, $\mathrm{H}$ - height $(\mu \mathrm{m})$; Freq $/ \mathrm{mm}^{-1}$ - rays per $\mathrm{mm}$; IM - Mineral inclusions. 
Acacia nigrescens, Combretum imberbe and Pericopsis angolensis. Narrow radial parenchyma was present in A. nigrescens, C. imberbe and Icuria dunensis. Although some species have positive aspects in one side, they must be analyzed as a whole. This happened with $P$. angolensis and I. dunensis: the first had larger rays and the other abundance of axial parenchyma. Both these traits can compromise drying quality.

(ii) Biodegradation - the presence of substances in heartwood and the abundance of extractives and gums directly affect the natural durability of wood. A previous study analyzed the resistance of Acacia nigrescens, Icuria dunensis and Pericopsis angolensis to biodegradation (Ali et al. 2011). They found that these species have high resistance to soft-, brown- and white-rot fungi and the termites Reticulitermes grassei and Mastotermes darwiniensis. All of our samples of $A$. nigrescens, I. dunensis and P. angolensis presented gums. The composition of gums includes a wide variety of chemical compounds which are variously colored (IAWA 1989). The presence of gums normally repels xylophagous microorganisms.

(iii) Permeability - it is important to preserve treatments, bonding, drying, application of varnish and others finishes. This property is especially influenced by vessel dimensions, frequency and obstruction (Ahmed et al. 2011). In the studied species, dimensions and frequency of vessels were similar, only Pericopsis angolensis had smaller vessels with higher frequency. Studies indicated that this wood accepts bonding, varnishing and polishing (Lumbile y Oagile 2008). The wood of Acacia nigrescens is good for finishes with waxes and oils (Lemmens 2006).

(iv) Workability - abundant mineral inclusions impair processing, by wear of cutting tools and crusting of equipment used in vaporization and heating of wood (Ching et al. 2011). High silica content affects tool wear radius and edge recession in the woodworking industry (Cristovão et al. 2011). Mineral inclusions were present in Acacia

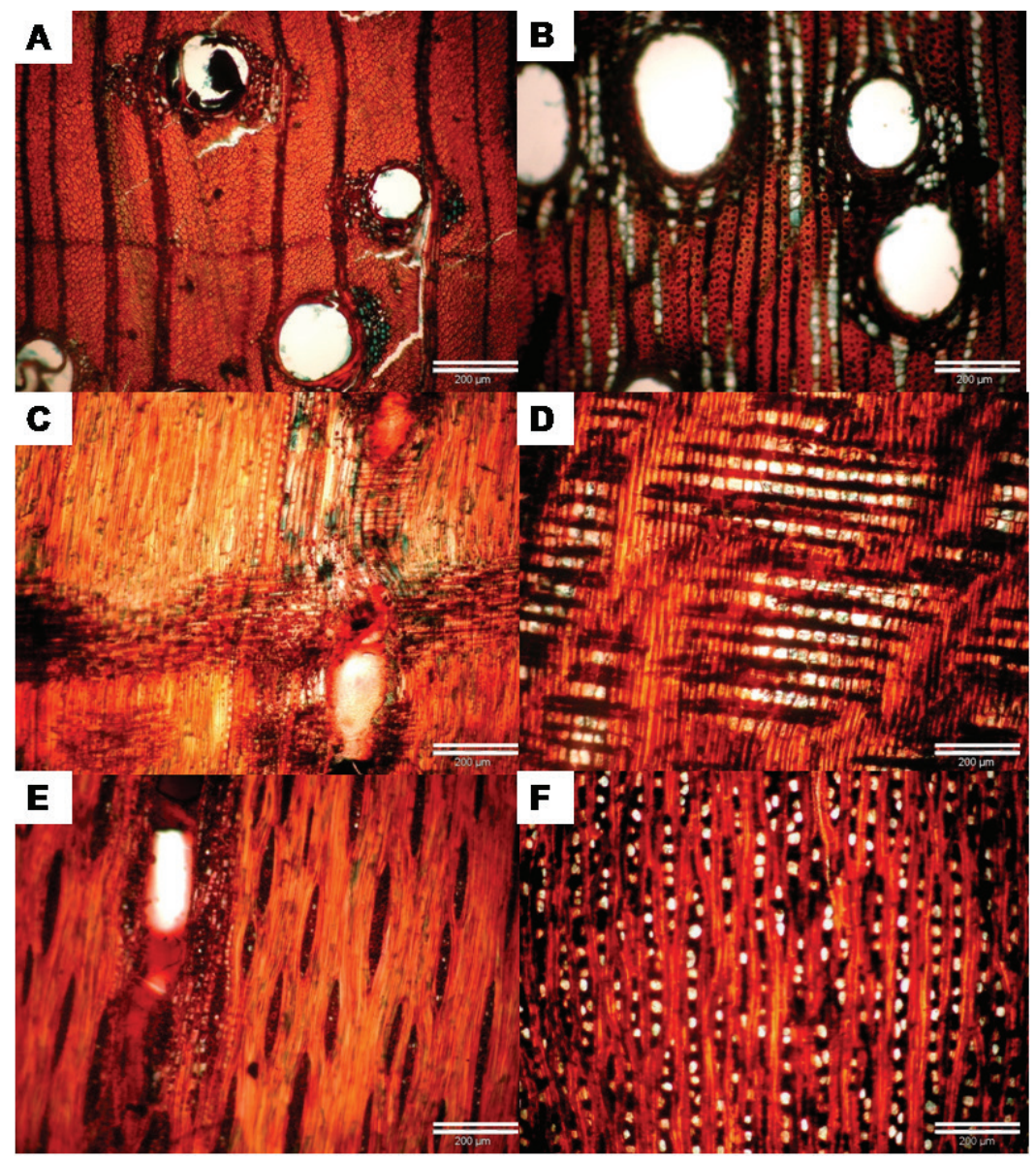

Figure 1. Acacia nigrescens wood (A,C,E) and Combretum imberbe wood (B,D,F); transversal section (A,B), radial section (C,D), tangential section $(\mathrm{E}, \mathrm{F})$. Scale bar $=200 \mu \mathrm{m}$.

Madera de Acacia nigrescens (A,C,E) y Combretum imberbe (B,D,F); sección transversal (A,B), radial (C,D), tangential (E,F). Escala = $200 \mu \mathrm{m}$. 


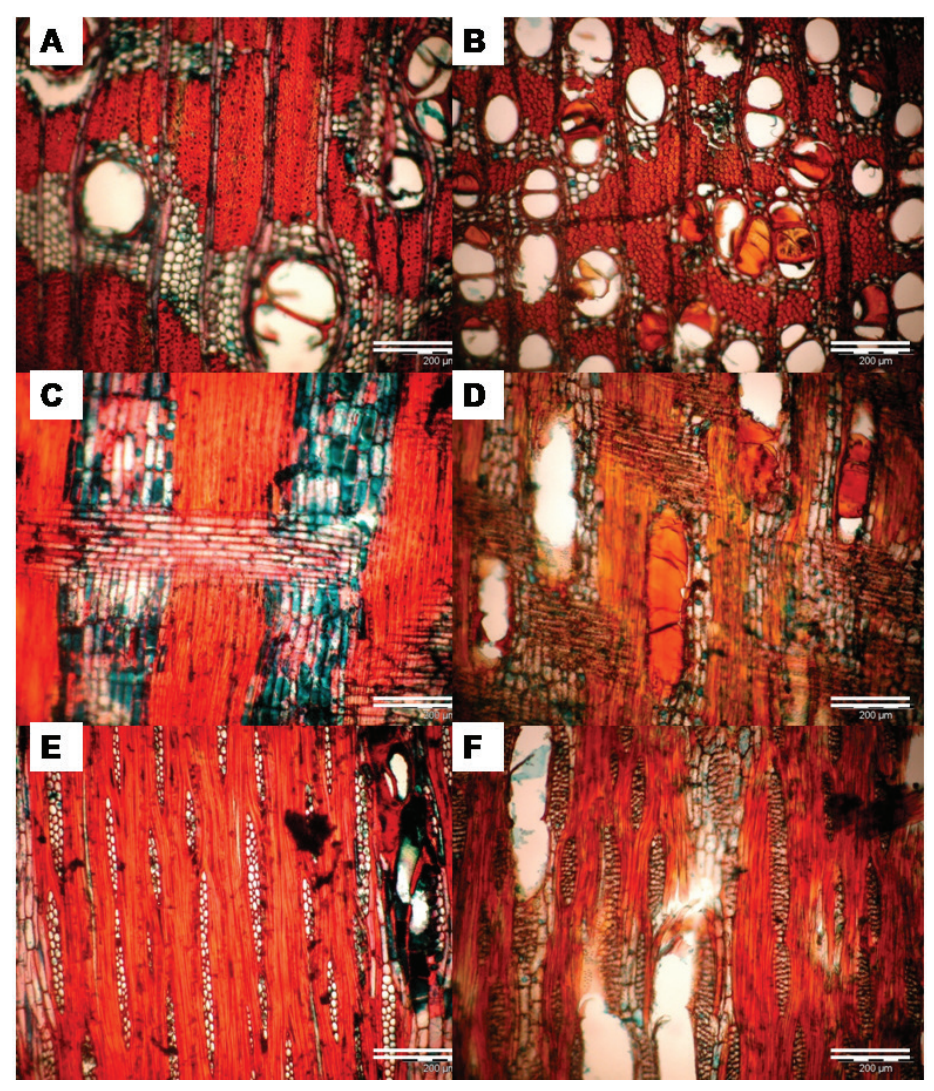

Figure 2. Icuria dunensis wood (A,C,E) and Pericopsis angolensis wood (B,D,F); transversal section (A,B), radial section (C,D), tangential section (E,F). Scale bar $=200 \mu \mathrm{m}$.

Madera de Icuria dunensis (A,C,E) y Pericopsis angolensis (B,D,F); sección transversal (A,B), radial (C,D), tangential (E,F). Escala = $200 \mu \mathrm{m}$.
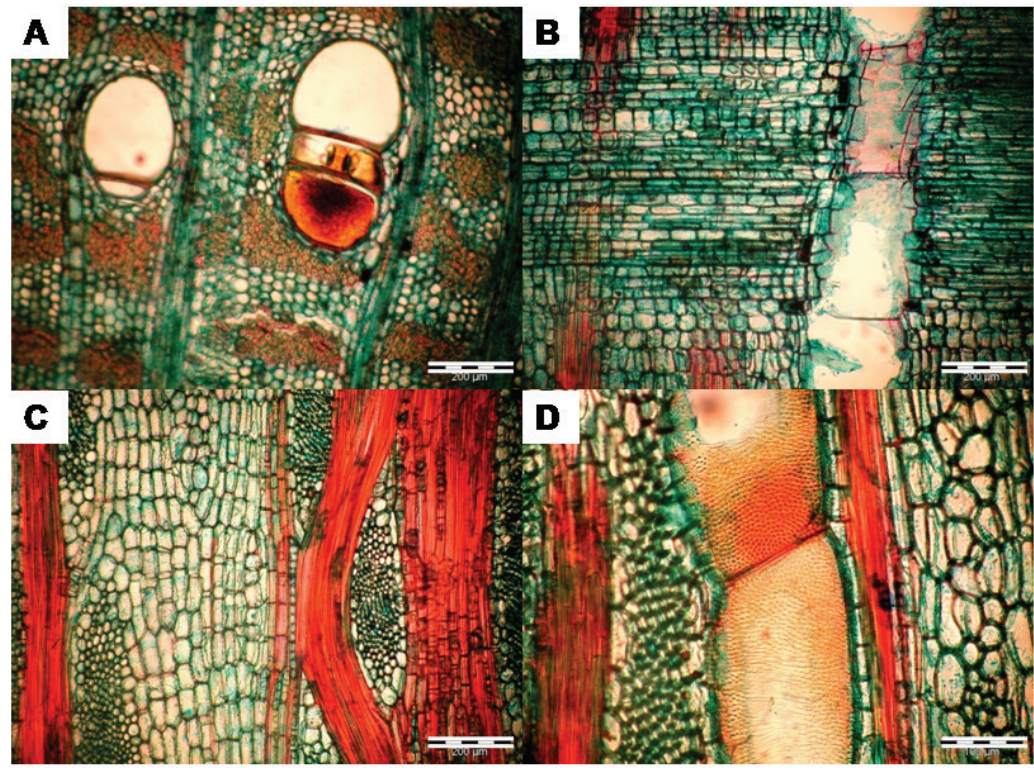

Figure 3. Sterculia appendiculata wood: transversal section (A), radial section (B), tangential section (C), scale bar $=200 \mu \mathrm{m}$. Intervessel pitting (D), scale bar $=100 \mu \mathrm{m}$.

Madera de Sterculia appendiculata: sección transversal (A), radial (B), tangential (C). Escala $=200 \mu \mathrm{m}$. Punteaduras intervasculares (D), Escala $=100 \mu \mathrm{m}$. 
nigrescens, Combretum imberbe, Pericopsis angolensis and Sterculia appendiculata. The high percentage of crystals in wood of Combretum imberbe explains its difficult workability but good durability, even in contact with soil (Lemmens 2009). Based on this characteristic, the wood of Icuria dunensis would have good workability and no problem with wear of cutting tools.

(v) Density and physical-mechanical properties - density has some influence on other physical and mechanical properties of wood and is influenced by anatomical and chemical composition. In the studied species, the vessel and ray dimensions and frequency, and fiber wall thickness can explain properties of density, shrinkage and resistance. The wood of Acacia nigrescens is considered highly dense (1,000 to $1,200 \mathrm{~kg} \mathrm{~m}^{-3}$ at $12 \%$ moisture content) (Lemmens 2006), the wood of Icuria dunensis has a density of $907 \mathrm{~kg} \mathrm{~m}^{-3}$ at $12 \%$ moisture content and an anisotropic coefficient of $1.3 \%$ (Ali et al. 2010). The wood of Pericopsis angolensis is heavy, with a density of 930-1030 $\mathrm{kg} \mathrm{m}^{-3}$ at $12 \%$ moisture content and has low rates of shrinkage, difficult to saw and work because of its high density (Lumbile y Oagile 2008). On the other hand, the wood of Sterculia appendiculata is medium-weight, with a density of $580-780 \mathrm{~kg} \mathrm{~m}^{-3}$ at $12 \%$ moisture content (Cardoso 1964).

(vi) Structural use - the suitability of wood in internal or external structures is directly related to its natural durability, which depends on its anatomical structure and chemical composition (Irbe et al. 2012). Wood with high percentage of parenchyma tends to have lower natural durability. The species with most parenchyma was Sterculia appendicula$t a$, hence we do not recommend the use for external applications without preservative treatment.

Positive or negative aspects of species. Based on anatomic characteristics of each species, we comment about the potential application, nevertheless, its physical and mechanical properties must be evaluated before choosing it for a specific final use. Rules from Ministério da Agricultura (2002) of Mozambique shows that for energy purposes, it is not allowed the use of wood from precious, first, second and third class. Therefore all species studied should not be applied for charcoal or firewood production, though it frequently occurs.

(i) Acacia nigrescens. Positive: presence of few parenchyma cells, good drying and low natural degradation; big vessels and few, good permeability; thick-walled fibers, high density. The darker color and high density could be interesting to applications in decks. High density could aggregate value for tables, bookcase, writing desks and others luxurious furniture. Production of edged glued panels (EGP) could also be an alternative of products with more aggregate value.

(ii) Combretum imberbe. Negative: presence of much mineral inclusion, wear of cutting tools. Positive: few and medium vessels, thick-walled fibers, high density; high natural durability. The species also presents potential uses as floor (darker color), external and internal structures (density and natural durability) and panels industry as decorative veneer or EGP. Turned objects could be another alternative.

(iii) Icuria dunensis. Positive: good resistance to biodegradation; few and medium vessels, thick-walled fibers. The wood could be applied in furniture, decorative veneers and plywood, and also in external structures, as decks or edged glued panels. Little pieces or residues can be used by artisans.

(iv) Pericopsis angolensis. Positive: small and numerous vessels, thick-walled fibers, high density. The wood could be applied for external structures, decks, floors and others uses where also aesthetic aspects are important, because visual figures and color are interesting. Residues of sawmills can be applied in wood craft.

(v) Sterculia appendiculata. Negative: many parenchyma cells, and low natural durability. Positive: very few and big vessels, and medium density influence its permeability, thus preserving treatments, varnish and other finishing properties can be easily applied in wood. One potential application is in fiber panels or decorative veneers, wood cement composites. Other possibilities are production of toys or turning objects.

\section{CONCLUSIONS}

In general, the species present diffuse pores, simple perforation plates, alternate intervessel pits and deposits in vessels, abundant axial parenchyma, multiseriate rays; very thick-walled fibers and mineral inclusions. Percentage of axial parenchyma can compromise drying quality of Pericopsis angolensis, Icuria dunensis and Sterculia appendiculata; percentage of mineral inclusion can affect workability of Combretum imberbe. Based on these anatomical characteristics, the species have good potential for industrial use as decorative panels, plywood, furniture, floor, structures and craft. We recommend the analysis of physical and mechanical properties to indicate an adequate application of each species.

\section{REFERENCES}

Ahmed SA, SK Chun, RB Miller, SH Chong, AJ Kim. 2011. Liquid penetration in different cells of two hardwood species. Journal of Wood Science 57(3):179-188. DOI 10.1007/ s10086-010-1168-4.

Ali AC, E Uetimane Jr, IA Lhate, N Terziev. 2008. Anatomical characteristics, properties and use of traditionally used and lesser-known wood species from Mozambique: a literature review. Wood Science and Technology 42(6): 453-472. DOI:10.1007/s00226-008-0186-5.

Ali AC, J Chirkova, N Terziev, T Elowson. 2010. Physical properties of two tropical wood species from Mozambique. Wood Material Science \& Engineering 5(3-4): 151-161. 
DOI: $10.1080 / 17480272.2010 .489649$

Ali AC, E Uetimane Jr, U Råberg, N Terziev. 2011. Comparative natural durability of five wood species from Mozambique. International Biodeterioration \& Biodegradation 65(6): 768-776. DOI:10.1016/j.ibiod.2011.03.010.

Bouriaud O, J-M Leban, D Bert, C Deleuze. 2005. Intra-annual variations in climate influence growth and wood density of Norway spruce. Tree Physiology 25(6): 651-660.

Cardoso JGA. 1964. Sterculia appendiculata. Madeiras de Moçambique. Maputo, Mozambique. Direcção dos Serviços de Agricultura e Florestas. 17 p.

Carlquist S. 2001. Comparative wood anatomy: systematic, ecological and evolutionary aspects of dicotyledon wood. 2nd ed. Berlin, Germany. Springer Verlag. 379 p.

Ching TW, T Nobuchi, MH Sahri, LC Yu. 2011. Formation and distribution of calcium crystals in the trunk of Hopea odorata. Wood Research Journal 2(1):13-20.

Coradin VR, Muñiz GIB. 1992. Normas de procedimentos em estudo de anatomia da madeira. I - Angiospermae, II - Gimnospermae. Brasília, Brazil. SFB/Laboratório de Produtos Florestais. Série Técnica 15. 19 p.

Cristovão L, I Lhate, A Grönlund, M Ekevad, R Sitoe. 2011. Tool wear for lesser known tropical wood species. Wood Material Science and Engineering 6 (3): 155-161.

Damayanti R, S Rulliaty. 2010. Anatomical properties and fiber quality of five potential commercial wood species from Cianjur, West Java. Journal of Forestry Research 7(1): 53-69.

DNTF (Direcção Nacional de Terras e Florestas, MZ). 2009. Relatório de Balanço Anual de Terras, Florestas e Fauna Bravia. Maputo, República de Moçambique. Ministério da Agricultura. $50 \mathrm{p}$.

IAWA. 1989. List of microscopic features for hardwood identification. IAWA Bulletin 10(3):221-359.

Irbe I, G Noldt, U Grinfelds, A Verovkins, A Jansons, G Koch. 2012. Genetic variation of Norway spruce clones regarding their natural durability, physical and chemical properties. Advances in Bioscience and Biotechnology 3(8): 11041112. DOI: $10.4236 / \mathrm{abb} .2012 .38135$

ITTO (International Tropical Timber Organization, JP). 2012. Annual review and assessment of the world timber situa- tion. Yokohama, Japan. ITTO. $182 \mathrm{p}$

Lemmens RHMJ. 2006. Acacia nigrescens Oliv. Record from PROTA4U (Plant Resources of Tropical Africa). Wageningen, Netherlands. Acessed 9 may 2014. Available from http://www.prota4u.org/search.asp.

Lemmens RHMJ. 2009. Combretum imberbe Wawra. Record from PROTA4U. (Plant Resources of Tropical Africa). Acessed 9 may 2014. Available from http://www.prota4u. org/search.asp.

Lumbile AU, O Oagile. 2008. Pericopsis angolensis (Baker) Meeuwen. Record from PROTA4U. (Plant Resources of Tropical Africa), Wageningen, Netherlands. Acesso 9 may 2014. Available from http://www.prota4u.org/search.asp.

Marcati CR, CRD Milanez, SR Machado. 2008. Seasonal development of secondary xylem and phloem in Schizolobium parahyba /(Vell.) Blake (Leguminosae: Caesalpinioideae). Trees 22(1): 3-12.

Ministério da Agricultura. 2002. Regulamento da Lei de Florestas e Fauna Bravia. Decreto 12/2002. Maputo, Mozambique. p.1-45.

Ministério da Agricultura. 2007. Diploma Ministerial n.8/2007, 24 de janeiro de 2007. I Serie, n. 4. Maputo, República de Moçambique. Ministério da Agricultura p. 59.

MRE (Ministério das Relações Exteriores, MZ). 2015. Moçambique: comércio exterior. Maputo, República de Moçambique. Ministério das Relações Exteriores. 13 p.

Nakata PA. 2003. Advances in our understanding of calcium oxalate crystal formation and function in plant. Plant Science 164: 901-909.

Ogle A, I Nhantumbo. 2006. Improving the competitiveness of the timber and wood sector in Mozambique. Maputo, República de Moçambique. Washington, USA. Nathan Associates for USAID. $46 \mathrm{p}$.

Uetimane E, N Terziev, G Daniel. 2009. Wood anatomy of three lesser known species from Mozambique. IAWA Journal 30(3): 277-291.

Wieringa JJ. 1999. Monopetalanthus exit. A systematic study of Aphanocalyx, Bikinia, Icuria, Michelsonia and Tetraberlinia (Leguminosae, Caesalpinioideae). Wageningen Agricultural University Papers 99(4):246-247. 
